\title{
Jews and Cossacks in the Jewish Autonomous Region
}

\author{
Felix Ryansky
}

At a recent congress, Cossacks of Eastern Siberia and Far East of Russia demanded the abolition of the Jewish Autonomous Region (JAR). Most zealous Zionists supported this demand, since their primary goal is to bring world Jewry to Israel. However, the majority of the 200,000 Jews and non-Jews of the JAR, including approximately one hundred so-called "AmurCossacks," rejected this idea. The history of colonization of this tiny part of Russia, located on the left bank of the Amur river, was very dramatic. There were hardships throughout its history that continue today. At a time when the JAR is trying to rebuild its economy and construct new political and social relations and culture, some people raise their voices demanding its abolition.

The history of this region's settlement and development over the last 150 years can be divided into two acts. The first involves the Cossacks' settlement of the region. Most of them were killed or fled the region after the Revolution. The second act involves the creation of the Jewish Autonomous Region. The history of Jewish settlement is not devoid of violence either. There has also been a process of out-migration, but this process has been considerably less bloody and more gradual.

There are some Cossacks living outside the JAR who now demand that the Jewish Autonomous Region territory be returned to them. They argue that their ancestors arrived first and that Jews came to already-colonized territories. In fact, as will be seen later, both communities have contributed their hard labour to colonization and development of the region. Cossacks settled a narrow strip along the Amur

Felix Ryansky is a geographer, geologist and Director of the Institute of Complex Analysis of Regional Problems, Far East Campus of the Russian Academy of Science, Birobidjan, Russia. river. Jews were sent later to those parts that remained undeveloped.

\section{Act One: The Cossacks}

Cossacks constituted an important part of the Czar's military forces. They paid for theirfreedom from serfdom and taxes with a lifetime service to the Czar, so when the Czar sent them to settle the middle Amur valley, they could not disobey. They first arrived there in 1854, and between 1857 and 1860 they founded a number of still existing settlements

\section{At a recent congress, \\ Cossacks of Eastern Siberia and Far East of Russia demanded the abolition of the Jewish Autonomous Region (JAR). Most zealous Zionists supported this demand, since their primary goal is to bring world Jewry to Israel.}

along its left bank. A chain of small villages_stanitsas_formed the Russian frontier.

The beginning of the twentieth century brought some economic prosperity and military glory to the Amur Cossacks. They were granted land titles enabling them to farm. In addition, they were responsible for policing the trans-Siberian railway and newly discovered gold mines. As the Czar's military force, they had to defend the borders. During the war of 1904-05, they defeated the Japanese "Black Dragon." Even though Russia lost the war, the Cossacks won all battles with the Japanese along the border.

Due to a relatively high birth rate (each family had an average of five or six children), the population of Amur Cossacks in this region was approximately 15,000 by 1910 . At that time the population of non-Cossacks in this region was only 2,000 to 3,000 . The Cossacks settled a narrow strip $30-40 \mathrm{~km}$ wide along the Amur river. The region surrounding the trans-Siberian railway never belonged to them but was owned directly by the state.

The Amur Cossacks violently opposed the Bolsheviks' rule and their policies of land redistribution and collectivization. Their opposition to the Communist rule grew into a mass uprising in the spring of 1918. It is hard to estimate the number of those who perished in the bloody civil war and those who were still alive in 1921 when the Red Army occupied the Far East. According to some estimates, by 1923 there were no more than 600 Cossacks left in this region. They were those who either did not participate in the struggle against the Red Army or those who concealed their participation. Cossack stanitsi were virtually depopulated and gradually settled by migrants from the European part of the country, mainly Russians and Ukrainians. Koreans also came to live there. Thus the Cossack community as a territorial, linguistic, material and cultural unit with selfidentity was destroyed.

\section{Act Two: Jews}

In 1924 there were 2.2 million Jews in the SovietUnion. They were among the most deprived ethnic groups in the country. Their living standards were low and possibilities for mobility extremely limited. They were dispersed throughout the country where they faced antiSemitism on a daily basis. The Communist regime, which assumed the role of a protective "older brother" to all smaller nations, had to extend its" tender care" to these unfortunate people as well. For this purpose, the Executive of the Soviet of Nationalities formed the 
Committee on Land Distribution to Working Jews (KOMZET). The committee's mandate was to find a territory for Jewish settlement and help Jews migrate and settle there.

The population of the Far East was always low, but it experienced a dramatic decline during the years following the civil war. Considering the region's geopolitical significance, it is no wonder that the Soviet state took serious measures to settle it. It seemed that Jews who had no territory of their own in Russia would be happy to make the Far East their new home.

We do not agree with the popular image of the "expulsion" of Jews to the Far East. The Jewish case is very different from that of Volga Germans or Crimean Tartars. The latter two groups were moved forcefully to a new territory. Jews, on the other hand, had a choice and in fact most of them preferred to stay in their places of origin. They were exposed to ardent propaganda, but there was no coercion. Some high-ranking government officials tried to lure them to the Far East by painting a rosy picture of their future. In 1926 Kalinen, the president of the U.S.S.R., stated publicly that the government was interested in founding a Jewish republic [sic] in the BirskoBidjan region. (Until now its administrative status has never been more than that of a region.)

The idea of creating a Jewish region was rejected by Zionists and assimilationists among Soviet Jewry. For different reasons, both tried to prevent it, but some Russian Jews saw in it a possibility of acquiring a "promised land." These enthusiasts saw a parallel between their movement to the Amur River and their remote ancestors' exodus from Egypt. For them it was also a viable alternative to the settlement of Palestine, which was violently opposed by Arabs and mistrusted by the Turkish and later by the British authorities. In the colonization of the Far East they saw an opportunity of getting a vast territory for which they did not have to shed their blood. It seemed to them that perseverance and hard work would guarantee a reward. Generous financial support came from Ikor, an American
Jewish organization, which eased the pains of early settlement.

In 1930 Birsko-Bidjan was officially declared the Jewish National (not yet autonomous) Region. A group of 650 Jews arrived soon after. They cleared the marshesin the lowlandssurrounding the trans-Siberian railway. It was expected that meridians of Jewish villages crossing the taiga and the marshes would connect the trans-Siberian railway with the Amur River. Tikhinkaya Station was the centre of the Jewish settlement. Later it became the capital city, Birobidjan.

The newcomers faced extremely harsh living conditions that many were not prepared to accept, and the return migration was significant. Nevertheless, in 1937 the Jewish population reached efforts to please Moscow that they exceeded the required quota for agrarian population. Even among Jews residing in Birobidjan-which was the administrative, cultural and industrial centre of the JAR- 60 percent of the population was agricultural.

By the end of World War II and the years that followed it, the country's economic priorities were oriented towards restoring the industries destroyed in the war and encouraging their growth in new regions of the country. In this context, the idea of "agriculturating" the Jews came to an end, and they started moving into more familiar urban occupations. Birobidjan became the nucleus that attracted them.

\section{Strictly speaking, anti-Semitism is not evident in the JAR. The region's multicultural nature, its high degree of intermarriage and representation of Jews at all levels of the socio-economic ladder, have all prevented the growth of anti-Semitism. Yet the rise of nationalism and anti-Semitism in other parts of Russia alerts Jews residing in the JAR as well.}

17,000 , or 25 percent of the region's entire population.

The idea of a Jewish sovereign region, despite its limited autonomy and distance from the historic homeland, attracted numerous Jews from abroad. Among them were 116 Argentinian, 101 Lithuanian, 88 French, 83 Latvian, 65 German, 61 Belgian, 43 American and 30 Polish Jews. The most interesting fact is that among them were 74 people from Palestine.

However, by the beginning of World War II, the migration of Jews to the region virtually came to an end as did their dream of Jewish autonomy. Jews of the region were forced to become agricultural producers in collective farms. Local authorities received orders from Moscow to direct no less than $\mathbf{5 0}$ percent of the migrants to rural areas. Regardless of migrants' previous occupations-whether they were teachers, shoemakers or hairdressers - they were order to become collective farmers. Local authorities were so zealous in their
During the period of Gorbachev's reforms, the JAR's Jewish community underwent an amazing metamorphosis. First, it became clear that the community numbered many more than the 8,900 officially-registered Jews. In Birobidjan alone, 20,000 people claimed to be Jews. In addition, there were other settlements in the area densely populated by Jews. Second, a number of Jewish organizations emerged, including some for youth, women, culture and others. Third, Jews residing in the JAR got a chance to learn Yiddish. Yiddish was even taught in kindergartens and spoken on TV. There was an attempt to rebuild a synagogue that was destroyed in a fire thirty years earlier. The revival of Jewish culture was accompanied by democratization and reintroduction of private property. These processes gave hope for individual and ethnic self-expression. Living standards were rising and communication with relatives abroad improved significantly. During these years very few Jews were interested in 
emigration. Even though it became easier to emigrate to Israel between 1986 and 1988 , only twenty to thirty families did so.

The gradual decline of perestroika's potential for reform and its obvious failure by 1988 created much confusion. People became disappointed, impoverished and uncertain of the future. They feared the resurrection of the old regime. Ethnic conflicts tormented Russia, and ethnic groups with ties or roots abroad tried to leave. Attempts by "Pamyat" to stimulate a wave of anti-Semitic hysteria with all its consequences fuelled the departure of Jews. Strictly speaking, antiSemitism is not evident in the JAR. The region's multicultural nature, its high degree of intermarriage and representation of Jews at all levels of the socioeconomic ladder, have all prevented the growth of anti-Semitism. Yet the rise of nationalism and anti-Semitism in other parts of Russia alerts Jews residing in the JAR as well.

During 1989-91 about 2,000 Jews left the JAR. The Jewish Cultural Society in Birobidjan predicted that 2,000 to 3,000 more people would leave in 1992-93. However, the actual emigration rate turned out to be lower than expected for several reasons. First, Israel faced tremendous difficulties in settling Jews from the former U.S.S.R. Second, despite the economic crisis in Russia and the political destabilization, there are growing opportunities for economic advancement through private entrepreneurship. And finally, the revival of Jewish culture in Birobidjan, which is supported even by its Russian population, looks promising.

Undoubtedly, if the situation in Russia takes a turn for the worse, JAR will become less Jewish, but it is impossible for all Jews to leave. Despite the JAR's economic weakness and slow formation of its national status, the local diaspora has consolidated and has formed its territorial identity. At the present time, after the latest wave of emigration, its leaders are taking measures to unite the community. Many are quite optimistic about its future, but there are also some developments that alarm the Jewish community. These have to do with the revival of Cossackdom, some factions of which are interested in gaining control over the territory of the JAR.

\section{Relations Between Cossacks and Jews}

The first Jewish settlers came to live among the Cossacks of the Far East in 1928. Cossacks hoped they would help them rebuild the area devastated by the civil war. They believed that if Jews settled there, there would be no more repression, no more fighting, and that the government would send them aid to repair roads and plant their fields. Recognizing the relatively high level of education among the Jews, their hosts offered them jobs as teachers.

It is not our objective to paint an idyllic picture of harmonious relations between the Cossacks and Jews, but it is important to emphasize that the Cossacks of the time, despite their low levels of education and harsh living conditions of the time, were not hostile towards Jews. They blamed the new Communist regime for their misfortunes, while holding no grudge against those whom they perceived as weaker.

Recent years have witnessed the revival of Cossackdom throughout the former Soviet Union, including the JAR where the Cossack community comprises one hundred people. They aim to recreate the culture and traditions of their ancestors. In most cases, it is impossible to prove their genealogical ties to the early Cossack communities. While they are trying to revive some noble aspects of Cossackdom, their ideas and activities cause alarm among many people as well. Among the Amur Cossacks, there is a faction that claims the JAR lands belong to them. Some of them are ready to take up arms if a Jewish republic replaces the Jewish Autonomous Region. These tendencies may destabilize the region, blocking its further economic and political development. If Cossacks grow into a stronger force, many Jews who are presently optimistic about their future in the region will start packing.

\section{CALL FOR PAPERS Speclal losue on Refugee Crisis in Africa}

Most countries in Africa continue to experience severe refugeecrisis in the last two decades, due to political tyranny, mismanagement and adverse environmental changes. The Centre for Refugee Studies will publishaspecialissue of Refizge on this crisis, and papers are now being invited on the following issues and other related areas for consideration:

- The genesis of refugee crisis in modern Africa, and the effectiveness of development assistance programs.

- Refugee situation in the Horm of Africa and southern Africa

- Reintegration of returnees in countries like Angola, Namib. ia and South Africa

- Political and economicimpacts of refugees in host countries

Submission deadline:

A 200-word abstract should be sent to the editor by January 1 , 1993 and the deadline for submission is January $20,1993$. Early submissions will be most appreciated. The paper length may not exceed 3,500 words (or about 15 double-spaced pages). Submissions may also be sent on disc or by E-mail.

For further details, pleasecontact:

The Editor, Refuge

Centre for Refugee studfes

Suite 321, York Lanes

York University

4700 Keele Street, North York

Ontario, Canada M3j 1P3

Tel: (416) 736-5663

Fax: (416) $736-5837$

E-mail via BITNET, address:

REFUGE@YORKVM1 